\title{
Development of Listening Learning Multimedia Based on Metacognitive Strategies for Intermediate Indonesian for Speakers of Other Language (BIPA) Learners
}

\author{
Widi Astuti ${ }^{1} \&$ Nurhadi Bewe ${ }^{2}$ \\ ${ }^{1}$ Indonesian Language and Literature Education, Graduate School, Yogyakarta State University, \\ Karangmalang, Indonesia \\ ${ }^{2}$ Indonesian Language and Literature Education, Faculty of Languages and Arts, Yogyakarta State \\ University, Karangmalang, Indonesia \\ Correspondence: Widi Astuti, Yogyakarta State University, Karangmalang, Indonesia. \\ Email: widi.astuti2016@student.uny.ac.id
}

Doi: $10.23918 /$ ijsses.v7i3p154

\begin{abstract}
This study aims to develop listening learning multimedia based on metacognitive strategies for intermediate BIPA students and to describe the feasibility of these products based on the validation of material experts and media experts. This research is a development research with a modification of the Borg \& Gall development model, which includes the stages of information collecting, product development planning, product development, and product evaluation. The research instruments used are interview guides, needs analysis questionnaires, and product feasibility questionnaires. Data collection techniques employed are interviews and questionnaires. Descriptive statistics is used to analyze the product feasibility. The results of this study show that (1) the creation of listening learning multimedia based on metacognitive strategies are feasible for intermediate level BIPA learners, (2) based on material expert judgment, learning multimedia obtained a score of 4.58 out of a scale of 5 with the category of "very good", while based on assessment of media experts, learning multimedia obtained a score of 4.45 from a scale of 5 with the category "very good". Based on these findings, this learning multimedia can be used as an alternative of learning media for listening in the intermediate level of BIPA.
\end{abstract}

Keywords: Learning Multimedia, Listening, Metacognitive Strategies, Intermediate Level BIPA Learners

\section{Introduction}

Along with the reinforcing of Indonesia's position in the international level of various fields of life, the Indonesian for speakers of other languages (Bahasa Indonesia bagi Penutur Asing/BIPA) is increasingly recognized by the international community. There is an increasing number of foreign speakers with various backgrounds and goals to learn the Indonesian language and culture, both in their country and coming directly to Indonesia. Most of the international students who learn Indonesian by coming directly to Indonesia come from several universities in China. These students usually undergo a credit transfer program for one or two semesters in Indonesia to deepen their Indonesian language skills. Usually, they are at the intermediate level, primarily since they have studied Indonesian for four semesters at their home university. Intermediate BIPA students are students who can carry out daily conversations in Indonesian (Muliastuti, 2017).

Like other foreign language learning, BIPA learning includes learning language and cultural skills. Language skills include listening, speaking, reading, and writing (including vocabulary and grammar that can be integrated into these four aspects). Meanwhile, the cultural aspect includes 
everything related to the culture of the speakers of the target language. This cultural learning is essential so that there is no misunderstanding between BIPA students and the target language-speaking community, mostly if they live in Indonesia. It is undeniable that every day they will communicate with native speakers of Indonesia, so understanding this culture is very important to be possessed. Furthermore, foreign language teachers should provide cultural materials to their learners. Material about culture is not seen as something that stands alone or separates from language learning but it must have a particular context (Kramsch, 2001). It is intended that learners can use their language skills according to the context of the target language.

Listening is one of the language skills that BIPA students must master to communicate effectively. The idea is in line with the opinion of Rost (2011), who stated that the development of listening skills is a crucial element for the development of other language skills. However, listening in a second or foreign language is not as easy as listening in mother tongue or first language. Moreover, listening is the skill that is least understood and the least researched (Vandergrift, 2007). When students do not know how to listen effectively, students will have difficulty in the process of listening so that the response given in communication is not appropriate. Therefore, learning in the classroom for BIPA students becomes something that needs special attention.

However, so far, listening learning in BIPA classes has still encountered various obstacles. Based on a preliminary study conducted by Astuti \& Nurhadi (2019) on 49 intermediate-level BIPA students from Guangdong University of Foreign Studies (hereinafter written as GDUFS), Yunnan Minzu University (hereinafter written as YMU), and Guangxi University for Nationalities (hereinafter written as GUN) which currently undergoing a credit transfer program at Yogyakarta State University (hereinafter written as UNY) and Ahmad Dahlan University (hereinafter written UAD), some information related to listening learning is obtained as follows. First, the three main difficulties that BIPA students face in listening to the Indonesian language are (1) unknown vocabulary, (2) too fast speech, and (3) unclear speaker's accent. The three difficulties in listening experienced by BIPA learners are in line with Brown's (2017) opinion, which states that speaker's speed, speaker's speaking style, and incomprehensible vocabulary are the three difficulties experienced by language learners when listening to a second language or a foreign language. Second, to support the development of listening skills, most students stated that they needed to watch in the form of audio and video containing monologues and dialogues. Third, students state five topics they want to listen to, namely socio-culture, tourism, the environment, education, and entertainment.

In addition to the perspective of these students, Astuti \& Nurhadi (2019) also obtained listening teaching information from the lecturers. Based on interviews with lecturers of listening skills at UNY and UAD, the obstacles in listening learning are the mismatch of listening material, low motivation to practice listening to students, and technical obstacles such as malfunctioning speakers or projector in the classroom. Based on these findings, solutions are needed to overcome various obstacles in listening learning for intermediate BIPA learners. One of the solutions that can be used to overcome these obstacles is the use of instructional media.

One of the types of learning media is multimedia. Learning multimedia is usually computer-operated and provides feedback for students. Moreover, it has been widely used in learning second and foreign languages, especially listening, because the use of multimedia can help students in improving their 
listening skills. The use of multimedia in learning a second or foreign language offers a variety of benefits. Using learning multimedia gives several benefits, such as accommodating differences in students' learning styles, giving students the freedom to choose which materials to study, and giving students the freedom to adjust their learning speed by selecting specific buttons provided in learning multimedia (Cairncross \& Mannion, 2001). With the various benefits of learning multimedia, teachers and learners can make use of it in listening learning, both inside and outside the classroom.

One good example of multimedia in listening learning to a second language or foreign language is 123LISTEN made by Jan de Jong. This multimedia was created to help learners practice listening in English as a second language or a foreign language (Hulstjin, 2003). Apart from Jan de Jong, Brett (1997) also made learning multimedia for listening with various features to help language learners in listening to audios in English. Next, Brett conducted a comparative test to compare the effectiveness of listening by using multimedia and by using recordings (audio or video) only. Based on the results of Brett's research, it was concluded that students' listening comprehension was higher when they are using multimedia compared to using recordings (audio or video). Therefore, Brett suggests using learning multimedia for listening in a second language or foreign language learning. In the realm of BIPA, multimedia development has not been done much. One of the learning multimedia that has been developed is an interactive e-book by Megawati (2014). The e-book consists of two chapters/themes. With an integrative approach, this e-book is useful for improving the Indonesian language skills of BIPA students from Thailand.

In addition to the use of learning multimedia, the application of learning strategies also needs to be considered in language learning. This notion is in accordance with the opinion of Oxford (1990), which states that learning strategies are essential to pay attention to in language learning because by implementing these learning strategies, learners can be more active in learning to increase their communicative competence abilities. One of the listening strategies that can be applied to intermediate BIPA learners is metacognitive strategies. This strategy is a language learning strategy that consists of planning, monitoring, and evaluation stages. This strategy is a high-level thinking strategy because learners will evaluate how the thinking process is. This strategy emphasizes not only the result of listening but also the listening process. Thus, foreign language learners can become aware of the listening process so that they can evaluate themselves to develop their listening skills.

Based on the description that has been presented, it is necessary to do research and development listening multimedia based on metacognitive strategies for intermediate level BIPA students. This research and development aim to develop listening multimedia based on appropriate metacognitive strategies for intermediate level BIPA students. With this learning multimedia, intermediate level BIPA students can practice listening both inside and outside the classroom. Besides, the development of learning multimedia in the BIPA learning domain has not been done much so that the research and development of this learning multimedia can contribute to BIPA learning. 


\section{Theoretical Review}

\subsection{Learning Multimedia}

The term multimedia cannot be separated from the media. Smaldino, Lowther, \& Russell (2012) state that media is a means of communication. This term is the plural form of medium, which means "between" so that the term media can be interpreted as anything that carries information between the source and recipient of information. Learning media is anything that can be used to transmit messages from sender to receiver so that it can stimulate students' thoughts, feelings, attention, and interests so that the learning process occurs. The message referred to in this definition is learning material (Sadiman et al., 2003; Arsyad, 2014). Senders or sources of information are teachers, students, book authors, media makers, while the recipients of the information are both the student and the teacher.

Types of learning media can be classified from various sides. Media can be classified into six types, namely text, audio, visual, video, realia/model, and human (Smaldino et al., 2011). Along with the times, computer-based learning media emerged. One type of computer-based learning media is multimedia. Multimedia is a combination of various types of media to convey messages (Ivers \& Barron, 2002). Five elements in multimedia, namely text, images, sound, animation, and video (Vaughan, 2011).

Multimedia is usually run on a computer and is interactive, that is, able to provide feedback to students. Multimedia has been widely used in the process of learning a second language or a foreign language because this multimedia has various advantages or benefits. The use of multimedia provides options to make the teaching and learning process more interesting (Pun, 2013). In the BIPA learning realm, there are notable characteristics in terms of learning media. Kusmiatun (2015) states that learning media not only contains language learning materials but also contains cultural understanding because learning is implemented in a multicultural atmosphere. Language and culture will never be missed concerning language learning. Therefore, both things must be considered in language learning. One cannot learn the language without learning the target culture because someone who only masters the linguistic aspect by ignoring the cultural aspect is likely to experience misunderstandings in communicating with the target language speakers.

\subsection{Listening}

Listening is an activity that humans do every day. Rost (2011) states that there are four perspectives that can define the listening process, namely receptive, constructive, collaborative, and transformative. First, listening is a receptive process, which means capturing what the speaker is saying or accepting the transfer of thoughts, ideas, or ideas from the speaker. Second, listening is a constructive process, which means building or constructing the meaning of what is conveyed by the speaker. Third, it is a collaborative process, meaning that there is a speaker (interlocutor) or voice input (aural input) so that the listening process occurs. Fourth, listening is a transformative process because there is a creation of meaning through involvement, imagination, and empathy. The listening process can be done in two ways, namely bottomup and top-down. The bottom-up process is the listening process which is carried out from the process of perceiving language sounds and words in a speech, while top-down is the listening process which is carried out by processing the input as a whole and then constructing the meaning in it (Vandergrift \& Goh, 2009). 
There are various factors that influence the process of listening in a second or foreign language. Brown (2017) states that the four factors that influence listening activities are the factors from learners, teachers, input, and assignments. Learners usually complain about the speaker's speed and the speaker's speaking style and incomprehensible vocabulary. Goh (2000) also conducted a study which concludes that the difficulties of language learners in the listening process are (1) word recognition that they found it challenging to determine pauses between words, failing to recognize familiar words, and being stuck focusing on a word and losing focus on a full speech; (2) attention, which includes failure to capture the initial part of speech or text and distraction in concentration; and (3) the inability to form a coherent text representation (conclusion). In addition, learners sometimes find difficulty to listen to a second language or a foreign language because when listening, learners must activate all their sub-skills, such as receiving, understanding, remembering, evaluating, and responding to input (Renukadevi, 2014)

Listening in a second or foreign language is not as automatic as listening in the mother tongue. Chang, $\mathrm{Wu}$, \& Pang (2013) identified several problems related to listening learning experienced by second language learners, such as incomprehensible vocabulary, grammar, long sentences or speech, noise in class, and disturbances that occur in the input. In addition, uninteresting topics, attention, anxiety, speed of speech and accent, and the absence of repetition are also things that make it difficult for learners to listen. Therefore, listening skills in both the first and second or foreign languages need to be trained on learners so that they can communicate well in that language.

The learning process of listening to a second language or foreign language usually consists of three stages, namely pre-listening, while-listening, and post-listening (Richards, 2008). The pre-listening stage prepares learners for top-down and bottom-up processes through activities that involve prior knowledge, making predictions, and reviewing key vocabulary. The while-listening stage focuses on comprehension through exercises. The post-listening stage is filled with learners 'responses to listening comprehension and can also be filled by asking learners' opinions regarding topics that have just been heard. Richards (2008) adds that at the post-listening stage, teachers can help learners who still have difficulty understanding certain parts of listening.

\subsection{Metacognitive Strategies}

Flavell introduced the term metacognition in 1976 (Goh, 2017). This term refers to how a person thinks about his cognitive processes. There are two aspects to metacognition, namely metacognitive knowledge and metacognitive regulation (Vandergrift \& Goh, 2012). Metacognitive knowledge includes three dimensions, namely self-knowledge, task knowledge, and strategy knowledge. In learning to listen, selfknowledge can mean a person's understanding of himself about what factors can support or hinder the listening process from within himself, such as anxiety, limited vocabulary, or not being able to focus on listening. Task knowledge means a person's understanding of the task of listening, for example, the types of questions asked and the structure/organization of the text from the list. Finally, knowledge of strategies relates to learners' understanding of strategies that can be used to help learners to facilitate and improve their understanding in listening.

Meanwhile, metacognitive regulation consists of three stages, namely planning, monitoring, and evaluation. Goh (2008) explains that planning is determining the learning objectives of listening and how 
to achieve these learning objectives. Monitoring is checking the ongoing listening process, while evaluation is evaluating the process and results of learners in listening activities. In these three steps, there are strategies or methods that learners can use in listening to a second or foreign language. Vandergrift \& Goh (2012) states that the planning stage contains three ways that can be done, namely (1) advance organization, which means recognizing the organization or structure of the text or speech to be listened to, (2) organizational planning, which is planning how to do the requested task or what to do, and (3) selective attention, namely paying attention to certain parts, for example by paying attention to keywords.

Vandergrift \& Goh (2012) states that the monitoring stage contains monitoring comprehension and production monitoring steps. Monitoring comprehension is checking the learners' comprehension during the listening or reading process, while production monitoring is checking the students' oral and written production when the speaking and writing process occurs. The last stage is evaluating, which contains self-assessment activities. It involves evaluating how a person does a listening task, whether it is successful with the strategy used, or is still experiencing difficulties. Then the learner writes the results of these reflections to plan steps that might be taken in other tasks.

\section{Research Method}

\subsection{Research Design}

This research is research and development $(\mathrm{RnD})$. Borg \& Gall (1983) states that R\&D research, especially in the realm of education, is a process to develop and test the validity of educational products. Educational products can be in the form of material objects such as textbooks or learning media, as well as non-material objects such as teaching methods. The product developed in this research is listening learning multimedia with metacognitive strategies for intermediate BIPA learners.

\subsection{Research Procedure}

The research procedure used is a modification of the Borg \& Gall development procedure. The Borg \& Gall development procedure consists of 10 steps, whereas in this study, it only consists of four steps, which include (1) research and information collecting, (2) product development planning, (3) product development, and (4) product evaluation. At the information collection stage, researchers conducted interviews with two listening skill lecturers at UNY and UAD and distributed questionnaires to 49 intermediate-level BIPA students from GDUFS, YMU, and GUN. They were undergoing credit transfers at UNY and UAD. At the product development planning stage, the researchers analyzed the listening skill competency for intermediate level, determined listening learning designs with metacognitive strategies, and made flowcharts and learning multimedia storyboards.

At the product development stage, researchers followed up on things that had been made in the previous stage. There are three activities in this stage, namely developing multimedia content and making recordings/watching. The next stage is product evaluation. At this stage, learning multimedia is validated by media experts and material experts. In addition to providing scores, media experts and material experts also provide suggestions for improving learning multimedia to be revised. Then the researchers made revisions according to the suggestions given by material experts and media experts so that the learning multimedia developed was suitable for use in listening learning. 


\subsection{Data Collection Techniques and Instruments}

Data collection techniques in this study were questionnaires and interviews. Questionnaires are used when conducting preliminary studies and assessing learning multimedia through expert validation (expert judgment) from material experts and media experts. The instruments used were in the form of a need's analysis questionnaire and a product feasibility questionnaire for media experts and material experts. The product feasibility questionnaire uses a Likert scale with a range of 1 to 5. Meanwhile, interviews are used to conduct a preliminary study of two listening skills teachers in the BIPA program at YSU and UAD. The instrument used was an interview guide.

\subsection{Data Analysis Techniques}

The data analysis technique used in this study is descriptive statistics. The calculation process is as follows. First, sum up the score of each item in each aspect of assessment according to the assessment of media experts, material experts, and intermediate level BIPA students. Second, calculate the average score obtained from the summation of each aspect of the assessment according to the assessment of media experts, material experts, and intermediate level BIPA students. Third, convert the score into product quality categories.

Table 1: Guidelines for the Five Scale Conversion Formula

\begin{tabular}{|c|c|}
\hline Interval & Category \\
\hline $\mathrm{X}>\mathrm{Mi}+1.5 \mathrm{Sbi}$ & Very good \\
\hline $\mathrm{Mi}+0.5 \mathrm{Sbi}<\mathrm{X} \leq \mathrm{Mi}+1.5 \mathrm{Sbi}$ & Good \\
\hline $\mathrm{Mi}-0.5 \mathrm{Sbi}<\mathrm{X} \leq \mathrm{Mi}+0.5 \mathrm{Sbi}$ & Fair \\
\hline $\mathrm{Mi}-1.5 \mathrm{Sbi}<\mathrm{X} \leq \mathrm{Mi}-0.5 \mathrm{Sbi}$ & Pot good \\
\hline $\mathrm{X} \leq \mathrm{Mi}-1.5 \mathrm{Sbi}$ & Poor \\
\hline
\end{tabular}

(Widoyoko, 2013)

Notes:

$\mathrm{X}=$ actual score

Mi or the ideal average $=1 / 2($ maximum score + minimum score $)$

Sbi or ideal standard deviation $=1 / 6$ (maximum score - minimum score $)$

Based on the formula in Table 1, the following is the guideline for the assessment of the feasibility of learning multimedia on a scale of 5 along with its categories. 
Table 2: Guidelines for Converting Validation Results

\begin{tabular}{|c|c|}
\hline Average Score & Category \\
\hline $4.20<\mathrm{x} \leq 5.00$ & Very good \\
\hline $3.40<\mathrm{x} \leq 4.20$ & Good \\
\hline $2.60<\mathrm{x} \leq 3.40$ & Fair \\
\hline $1.80<\mathrm{x} \leq 2.60$ & Poor \\
\hline $1.00<\mathrm{x} \leq 1.80$ & Very poor \\
\hline
\end{tabular}

\section{Results of Research and Discussion}

This research produces a product in the form of listening multimedia based on metacognitive strategies for intermediate level BIPA students. This learning multimedia can be used with the help of a computer or laptop. The multimedia development process of learning is as follows.

\subsection{Research and Information Collecting}

To know the actual conditions of listening learning in the BIPA program and its problems, a preliminary study was conducted by conducting interviews and distributing questionnaires. Based on research by Astuti and Nurhadi (2019), the following preliminary study data were obtained. Interviews were conducted with two listening skills teachers at UNY and UAD. Lecturer 1 teaches students from GDUFS and YMU at UNY, while Lecturer 2 teaches students from GUN at UAD. The interview with Lecturer 1 was held on May 3, 2018, while Lecturer 2 was interviewed on May 7, 2018. Based on the results of the interview, the two teachers used a pre-listening, while-listening, and post-listening scheme for learning listening in class. Listening learning materials include listening to news, talkshow, films, fairy tales, and daily conversations. The material is adapted to the Common European Framework of Reference for Languages (CEFR) and the mapping of materials carried out by the Language Agency and Competence Standard Indonesian Language Courses and Training for Foreign Speakers (BIPA) Based on the 2016 Indonesian National Qualifications Framework. Teachers use audio and video in learning listening in classes that contain monologues and dialogues.

The obstacles faced by lecturers in learning to listen are sometimes malfunctioning of the speakers and projector in the classroom and the inappropriate reading material for intermediate BIPA students because the lecturer takes it from other sources. The mismatch of the material is in the form of vocabulary that does not match the topic and the tempo of listening is too fast. In addition, Lecturer 2 said that students had low motivation to practice listening outside the classroom. The lecturer stated that computer-assisted media or learning multimedia could be a solution to overcome these obstacles (Astuti \& Nurhadi, 2019).

A needs analysis was also carried out on intermediate level BIPA students. The needs analysis questionnaire was distributed to 49 intermediate-level BIPA students who were GDUFS, YMU, and GUN students. Based on the results of the questionnaire, students stated that the difficulty of the learners when listening was the unknown vocabulary meaning, the listening tempo was too fast, and the unfamiliar speaker accent. Students claim that they need monologues and dialogues that are packaged in audio and video form. The themes needed by students are socio-culture, tourism, environment, education, and entertainment. As many as $81.6 \%$ of students stated that they liked listening with the help of computers or 
multimedia. Thus, the development of learning multimedia must adapt to these findings (Astuti \& Nurhadi, 2019).

\subsection{Product Development Planning}

After conducting a needs analysis, the researchers planned to develop learning multimedia products. The information obtained in the previous stage formed the basis for planning product development. At this stage, the researchers analyzed listening skills that would be accommodated in learning multimedia, determined learning designs with metacognitive strategies, and makes flowcharts and storyboards.

First, the competency of listening skills in multimedia developed was based on the CEFR and the Passing Competency Standards (Standar Kompetensi Lulusan/SKL) of Indonesian Language for Foreign Speakers (Bahasa Indonesia bagi Penutur Asing/BIPA) Course and Training. There are six competency standards integrated into this learning multimedia, namely being able to understand (1) the main thoughts of radio or television programs related to daily news; (2) the main thoughts in a speech that are conveyed clearly and are related to general matters found while working, studying and relaxing; (3) the main ideas of radio or television programs related to various topics related to personal and occupational interests; (4) discussions/speeches/lectures with complex argument lines on familiar topics; (5) short Indonesian films with simple lines; and (6) Indonesian folklore.

The second step was to determine the design of listening learning procedures with metacognitive strategies to be applied in learning multimedia. Listening learning procedures with metacognitive strategies that were applied in learning multimedia are as follows. 


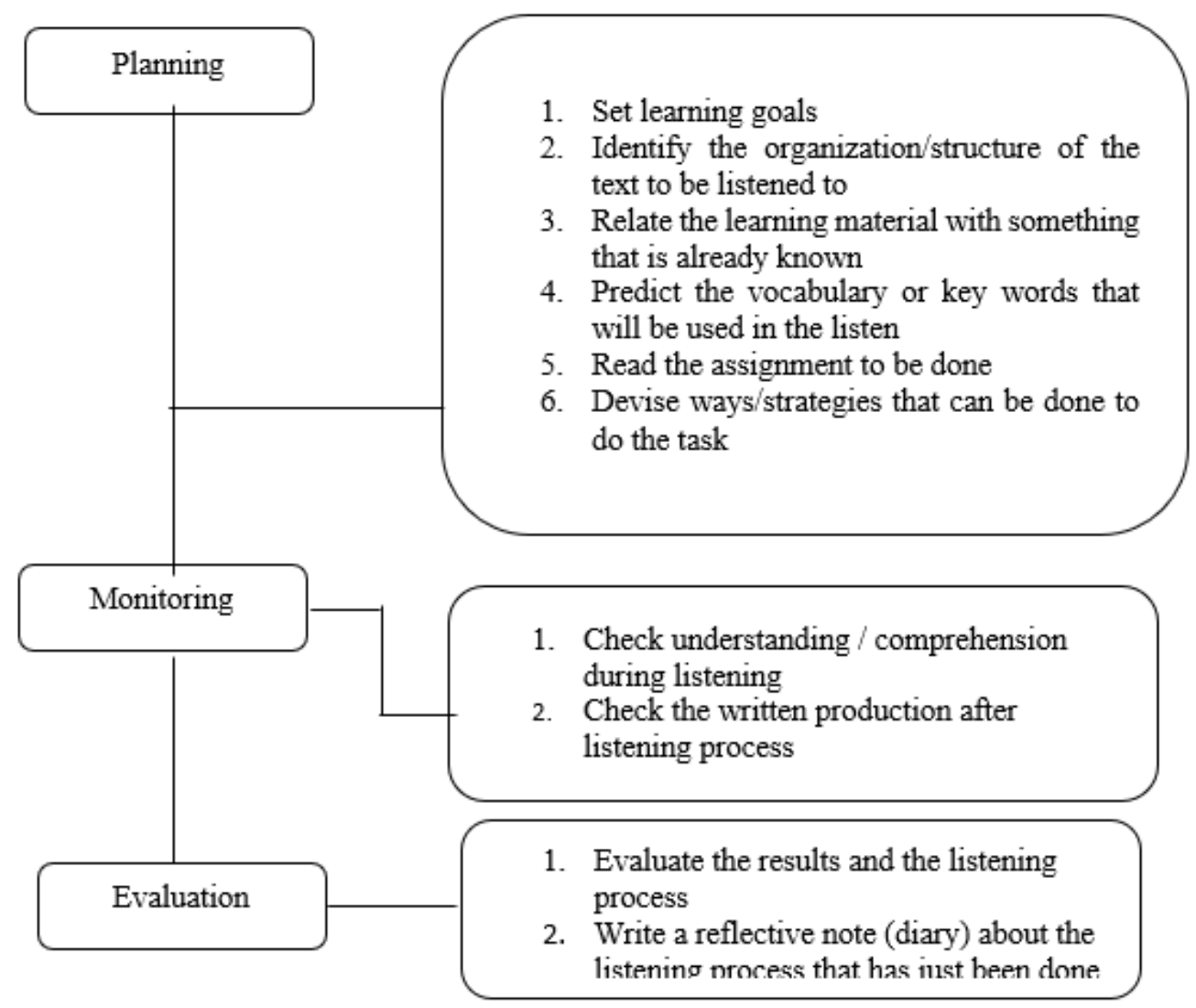

Figure 1: Metacognitive Strategies

Third, the researchers created flowcharts and storyboards. These flowcharts and storyboards were used as a guide for developing listening learning multimedia products. Flowcharts and storyboards were made with the help of Microsoft Word and Corel Draw X7 programs.

\subsection{Product Development}

At the product development stage, the researchers carried out two activities. First, developing and writing text. This stage includes the development of learning multimedia content. At this stage, the researchers wrote instructions for using multimedia, listening competence, learning materials, exercise, and evaluation, answer keys, developer profiles, and various writings needed in learning multimedia. The selection of the type and size of font used in learning multimedia is also considered to have good readability. The fonts used in this learning multimedia are Audio Wide, Arial, Berlin Sans FB, and Tw Cen MT Condensed Extra Bold.

Based on the theme chosen by the student, the researchers divided three topics for each theme so that there were 15 listings/topics in learning multimedia. Each topic is equipped with an image to introduce the context, questions related to the topic to relate a concept that learners already know with new information in the learning material, a brief description of the topic, and predictions of vocabulary that will be used in the listening. In addition, there are also practice and evaluation questions in the form of true-false, 
multiple-choice, completing gaps in a text, and essays. Exercise questions contain answer keys, while the evaluation option does not provide answer keys.

Second, recording the audio and editing the video. Audio in learning multimedia was developed by researchers with the assistance of peers. To make a recording, the first thing done was composing a script or text related to the topic to be listened to. Then, researchers and colleagues made a recording using an external microphone. The recorded dialog or monologue was then edited using the Adobe Audition program to eliminate noise. The videos used in learning multimedia were taken from YouTube and edited using Ulead Video Studio 11. After all the stages were carried out, the researchers combined these elements into listening learning multimedia by using Adobe Flash CS3 software.

\subsection{Product Evaluation}

After finishing making learning multimedia, the next step was product evaluation. This product evaluation stage used expert validation (expert judgment), i.e., material experts, and media experts. The material experts involved in the multimedia assessment of listening learning consisted of two lecturers from the Department of Indonesian Language and Literature Education, Graduate School, Yogyakarta State University. Both have experience in BIPA learning. Meanwhile, the media expert who validated this learning multimedia is a lecturer in the Education Curriculum and Technology Department, Faculty of Education, Yogyakarta State University. He has qualifications in the field of learning media evaluation. The following is a description of the multimedia validation of learning from these experts.

\subsubsection{Material Expert 1 Validation}

The material expert 1 in this research is Dr. Ari Kusmiatun, M.Hum. Material expert 1 validated the learning multimedia based on material and learning aspects through a product feasibility questionnaire. The material aspect got a score of 4.44, while the learning aspect got a score of 4.33. Overall, the material expert gave a score of 4.42. This score is in the "Very Good" category so that this learning multimedia is declared feasible.

In addition to scoring, material expert 1 provides suggestions for improvements for the product being developed. There are five aspects of learning multimedia that need to be revised. First, the material will be better if it is patterned based on the genre. Initially, not all the material presentation was patterned based on genre. On the advice of material experts, the presentation of the material is based on genre. Second, the term "cerita ulang" is replaced with the term "recount" or "rekon". Third, the sources of the images need to be included, even if they are privately owned. At first, some images were not included in the source in the product being developed. These images come from personal documentation and some are sourced from the internet.

Fourth, feedback or answer feedback on description questions needs to be considered. Learning multimedia contains two types of listening activities, namely listening activity 1 and listening activity 2 . The form of questions in listening activity 1 can be multiple choice, gaps in a text, and true-false, while the form of questions in listening activity 2 is in the form of description questions. Multiple choice, completing gaps in a text, and true-false questions can be immediately given feedback by the system using a programming language because researchers can provide probability answer keys for the three types of 
questions. In order to accommodate feedback for essay questions, there is a button to print. Thus, the lecturer can check the answer to the student's description questions directly to provide feedback, or the student can print the answer and submit the teacher so that they can be given feedback. Fifth, an inner CD would be better if it had a cover too. At first, there was no inner cover in learning multimedia that was validated by material expert 1 . The following is the cover display of learning multimedia.

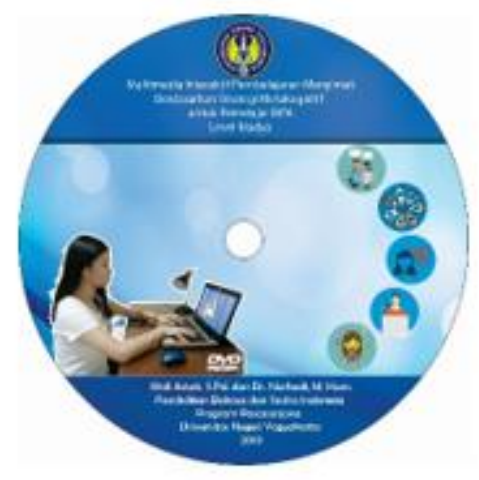

Figure 2: Inner Cover Figure

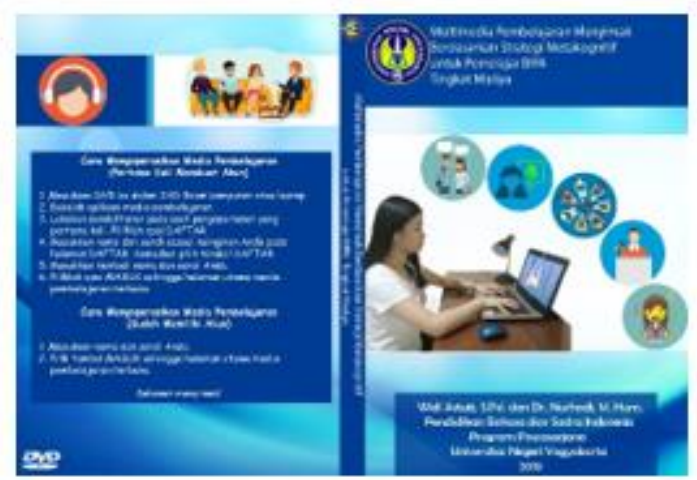

3: Outer Cover

\subsubsection{Material Expert 2 Validation}

The material expert 2 in this study was Prof. Dr. Suroso, M.Pd. Similar to material expert I, material expert II validated the learning multimedia based on material and learning aspects through product feasibility questionnaires. Based on the material aspect, learning multimedia got a score of 4.78, while from the learning aspect, multimedia got a score of 4.50. Thus, overall learning multimedia got a score of 4.75 . This score is in the "Very Good" category so that learning multimedia is declared feasible. Material expert 2 considered that learning multimedia is feasible and there were no suggestions for improvement. Based on the assessment of material expert 1 and material expert 2, learning multimedia got a score of 4.58 in the "Very Good" category. Thus, the learning multimedia is declared feasible.

\subsubsection{Media Expert Validation}

The media expert in this research is Estu Miyarso, M.Pd. The media expert's assessment is used to see the feasibility of learning media based on aspects of appearance and programming. There are three assessments in measuring the feasibility of this learning multimedia. In the first stage, learning multimedia obtained a score of 3.55, which was categorized as "Good", in the second stage, it obtained a score of 4.27, which was categorized as "Very Good" while in the third stage or the last stage of learning multimedia obtained a score of 4.45 which was categorized as "Very Good". Well".

The suggestions for the first stage of improvement from media experts are as follows. First, the typeface on the main page is replaced by a futuristic type. Initially, the font on the main page was Berlin Sans FB type; then, it was replaced with the futuristic Audiowide font. Below is the comparison of the main page before revision and after revision. 


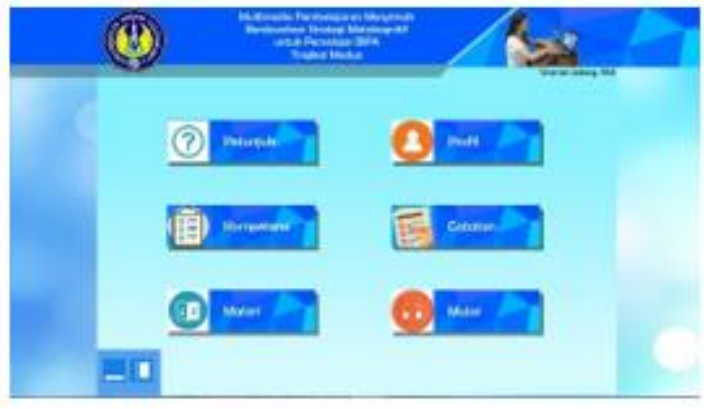

Figure 4: Main Page before Revision

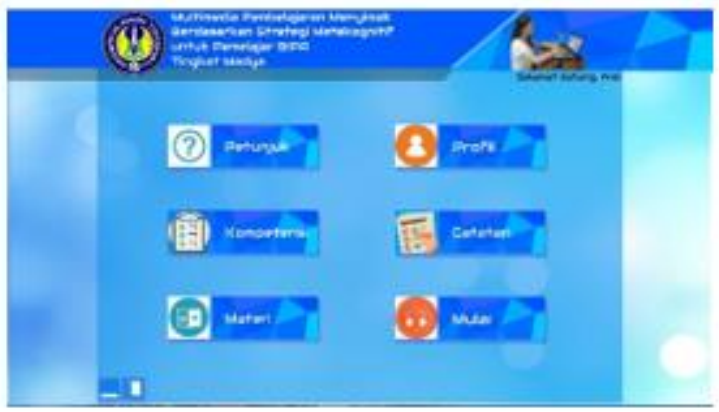

Figure 5: Main Page after Revision

Second, the background color is made softer. Initially, the background of the product being developed was bright green; then it was changed to blue. Here is the display of background color before and after revision.
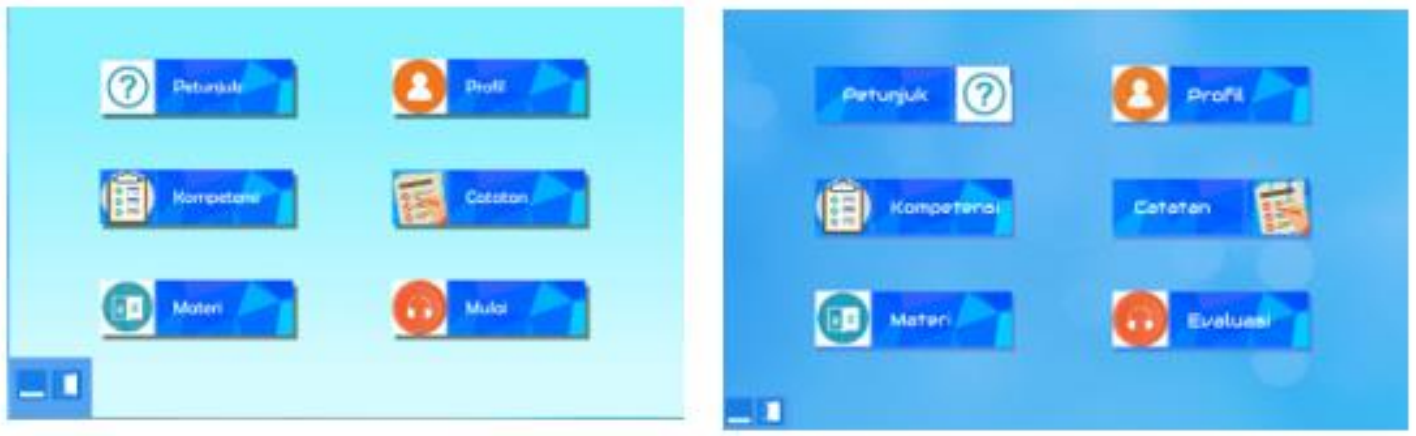

Figure 6: Background Color before Revision Figure

7: Background Color after Revision

Third, learning multimedia title is better left-aligned. Initially, the learning multimedia title had a center alignment; then, it was left-aligned. Below is the display of multimedia title before and after revision.

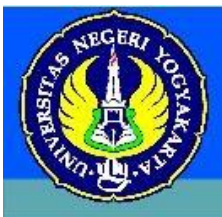

\section{Multimedia Pembelajaran Menyimak \\ Berdasarkan Strategi Metakognitif untuk Pemelajar BIPA \\ Tingkat Madya}

Figure 8: Multimedia Title before Revision

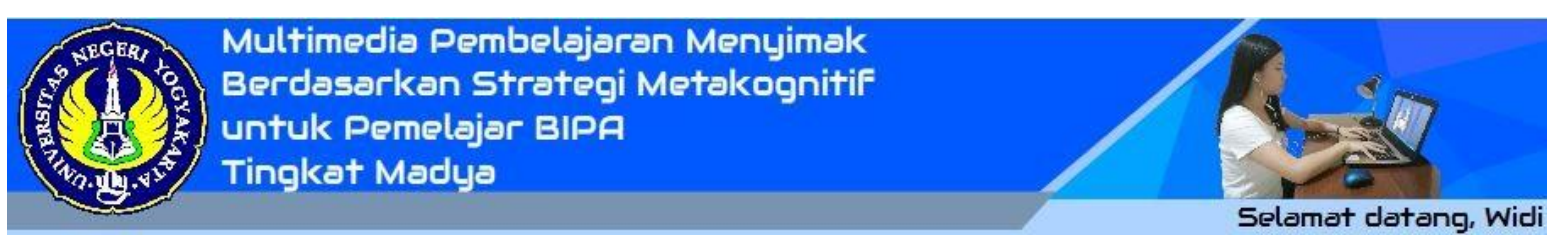

Figure 9: Multimedia Title after Revision 
Fourth, the font size is enlarged so that the user is comfortable. Initially, the font size was $12 \mathrm{pt}$ in learning multimedia; then, the researchers enlarged the font in the learning multimedia. Here is the display of font size usage before and after revision.

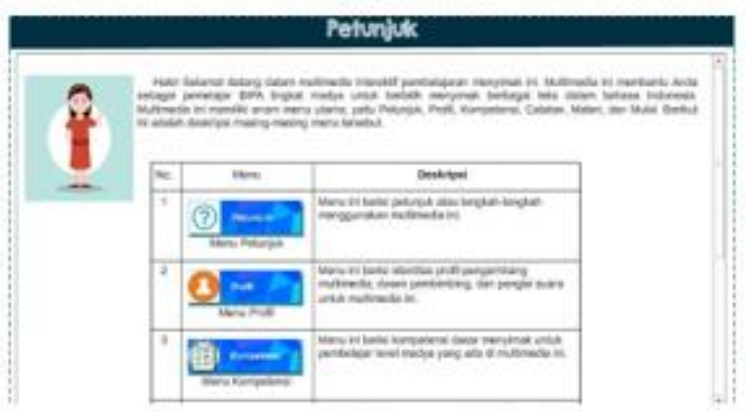

Figure 10: Display of Font Size Figure before Revision

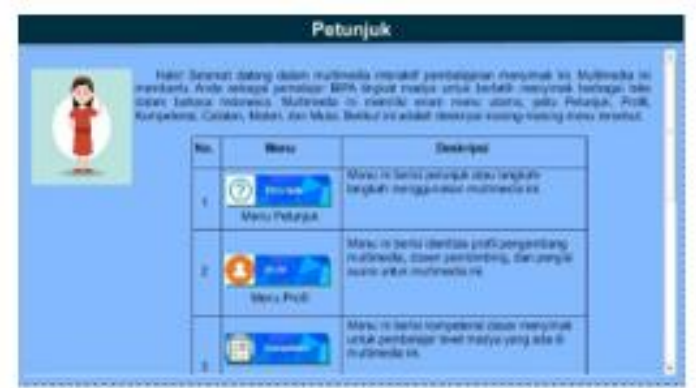

11: Display of Font Size after Revision

\section{Periksa}

\section{Kunci}

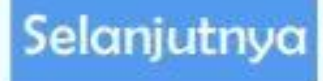

Figure 12: Button Display before Revision

\section{Check}

\section{Key}

\section{Next}

Figure 13: Button Display after Revision

Sixth, basic navigation buttons must be present on every page. These basic navigation buttons include the home, maximize/minimize, exit, and back buttons. This button is located at the bottom left of the learning multimedia. Initially, some pages or screens did not have basic navigation buttons, so a revision was made to that. Here is the display before and after revision. 


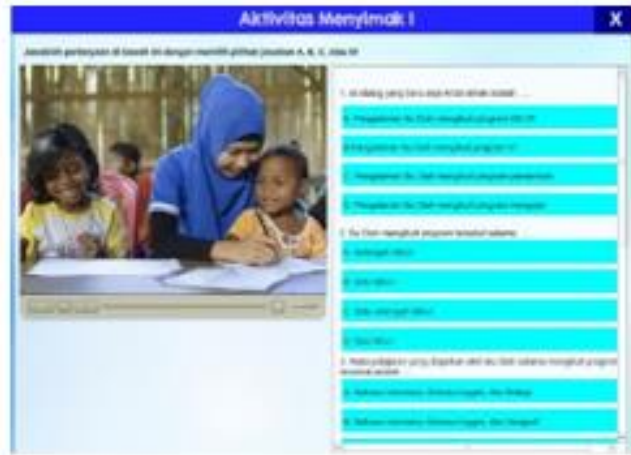

Figure 14: Page Display before Revision

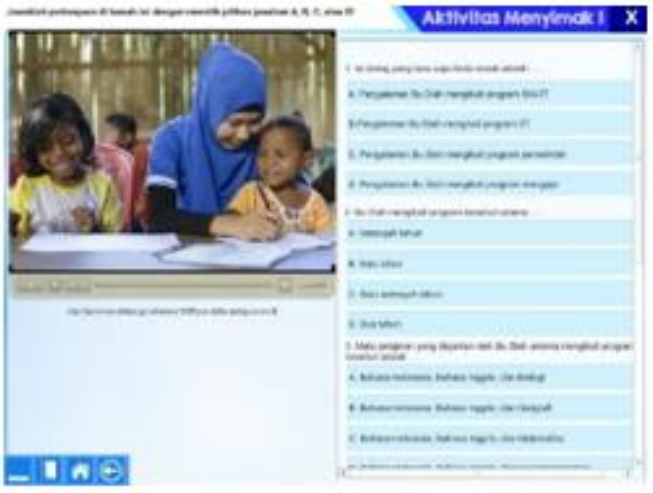

Figure 15: Page Display after Revision

Seventh, the colors on the multiple-choice exercise page are very sharp, so a softer color replaces them. Below is the color display in the multiple choices exercise page before and after revision.

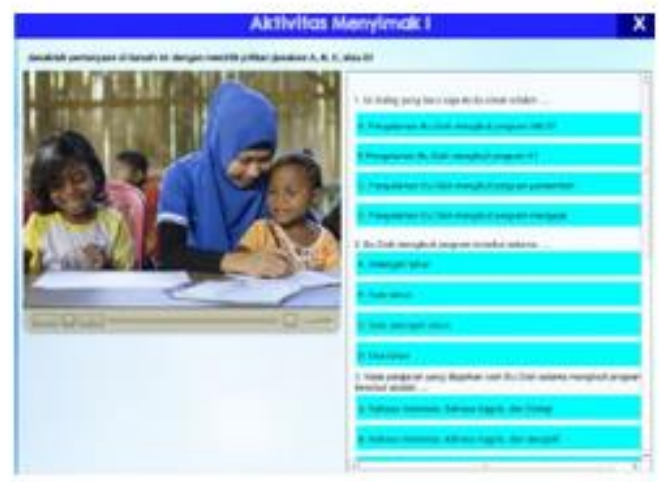

Figure 16: Color display in multiple exercise before revision

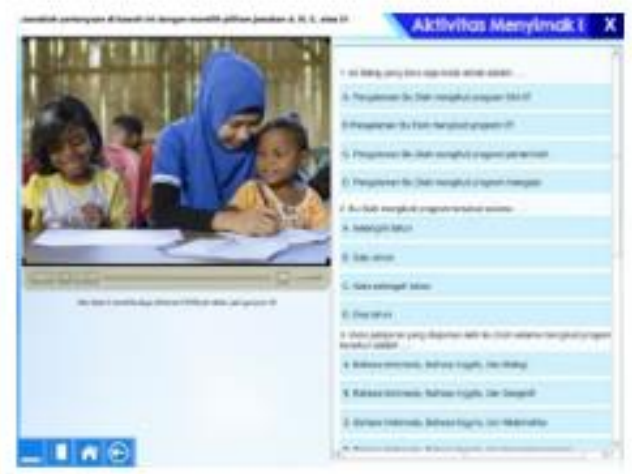

Figure 17: Color display in multiple exercise after revision 
Eighth, the fonts in "Pengetahuan Diri", "Pengetahuan Tugas", and "Pengetahuan Strategi", and "Mulai" are not appropriate. The font used initially was KG Second Chances Sketch. Based on advice from media experts, the font was changed to Arial. Here is the display of font before and after revision.

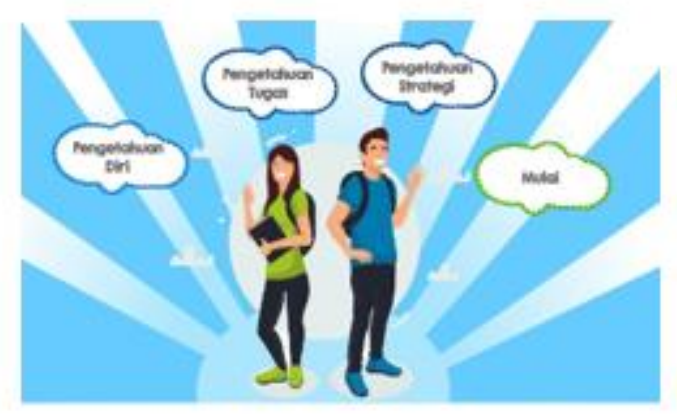

Figure 18: Display of font before revision figure

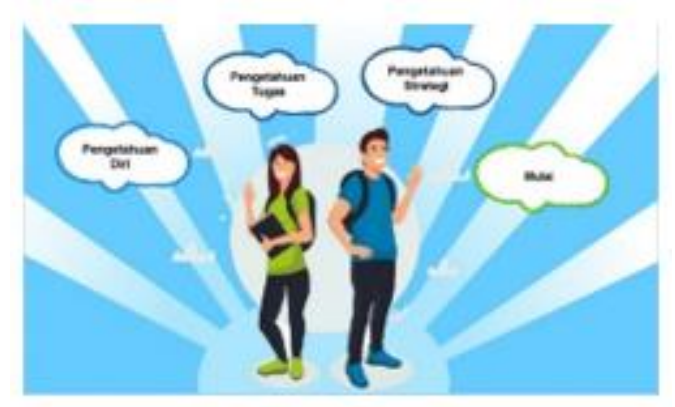

Figure 19: Display of font after revision figure

Ninth, the content on the "Profil" menu is too much, so that researchers minimize the contents on the "Profil" menu. Below is the "Profil" menu before and after revision.

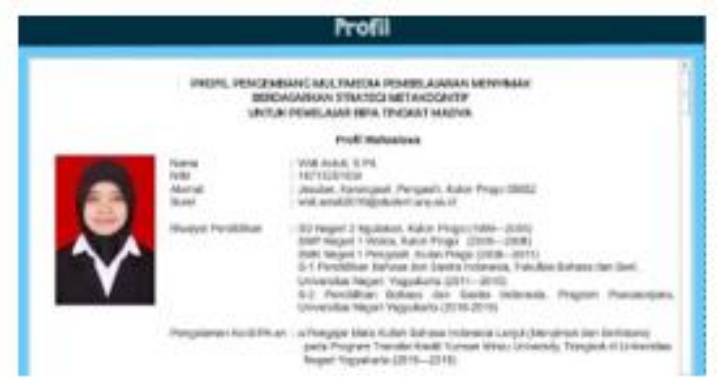

Figure 20: Display of "Profil" menu before revision 


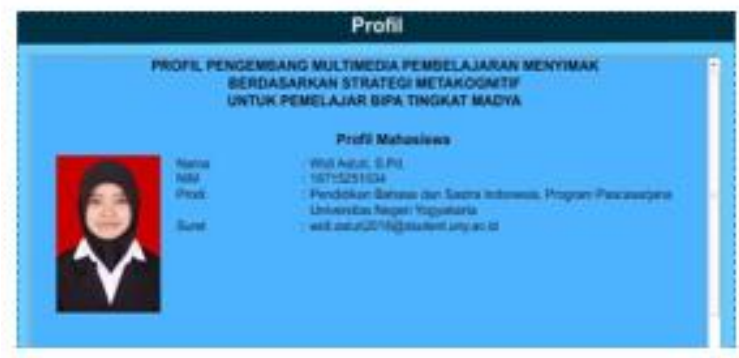

Figure 21: Display of "Profil" menu after revision

After revising the learning multimedia based on the advice of media experts, the researchers again validated the learning multimedia to a media expert. In this second validation, the media expert provided the following suggestions. First, the learning multimedia title should be made into three lines. Here is the learning multimedia title before and after revision.

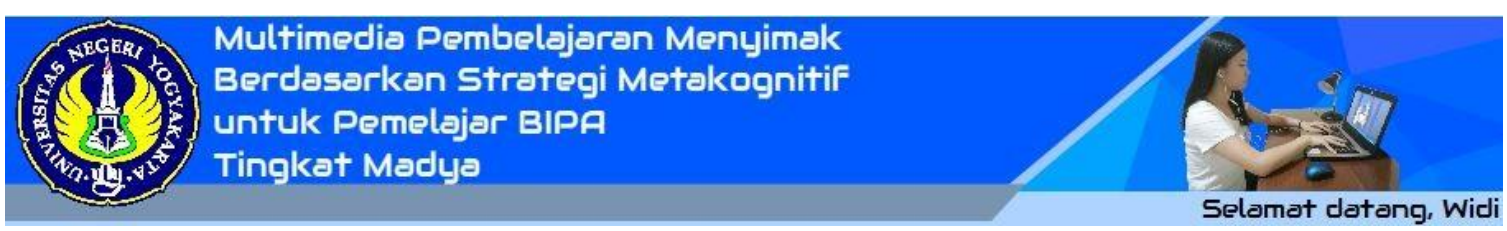

Figure 22: Learning Multimedia Title before Revision

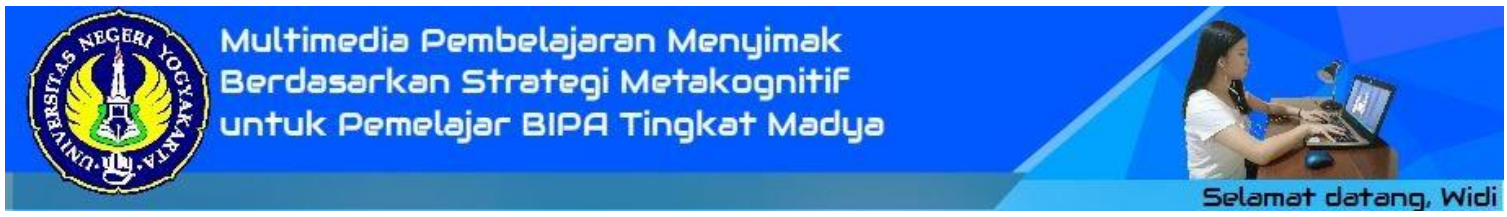

Figure 23: Learning Multimedia Title after Revision

Second, the font size is enlarged in the "Petunjuk" menu, descriptions on the "Materi" menu, and instructions for selecting vocabulary. Here is the display one of them before and after revision. 


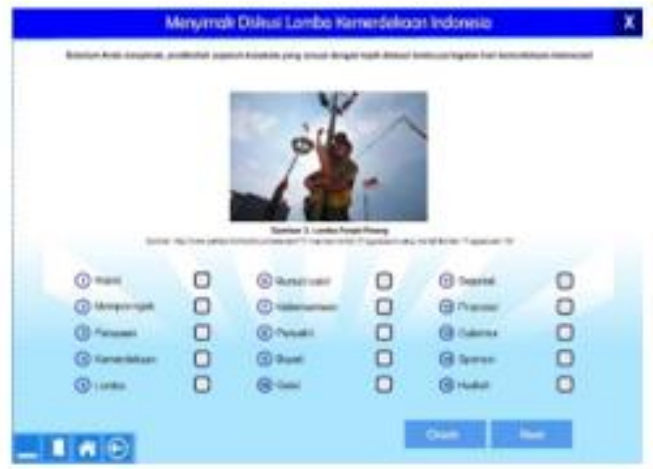

Figure 24: page display before revision

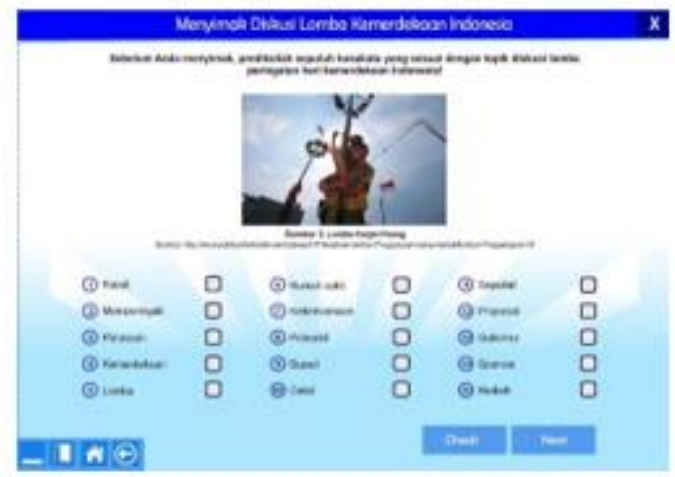

Figure 25: page display after revision

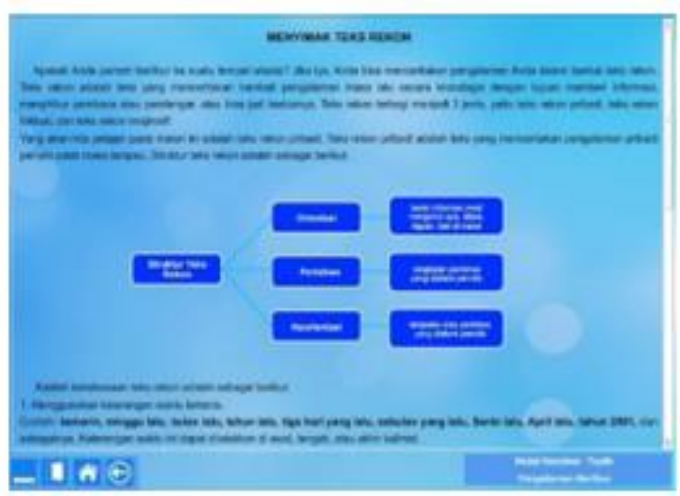

Figure 26: Material Display before Revision Figure 


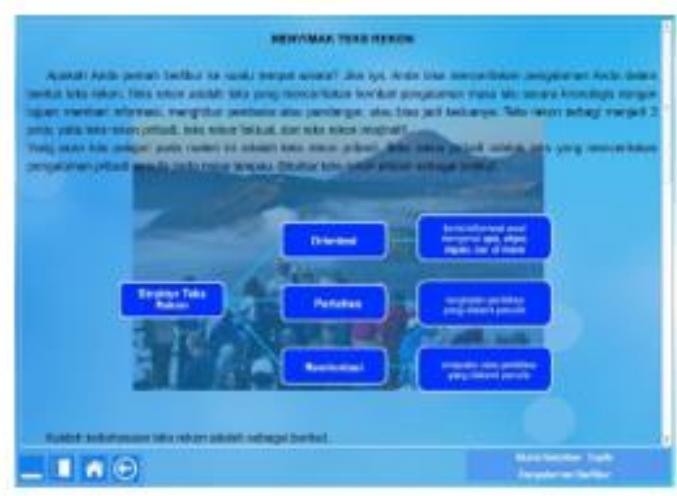

Figure 27: Material Display after Revision Figure

Fourth, the words "Pengetahuan Diri", "Pengetahuan Tugas", and "Pengetahuan Strategi" are revised because if they are minimized, only the words "Pengetahuan" are visible. In order to follow up the suggestion, the researcher changed the text property from dynamic text to static text. Here is the display of metacognitive knowledge page before and after revision.

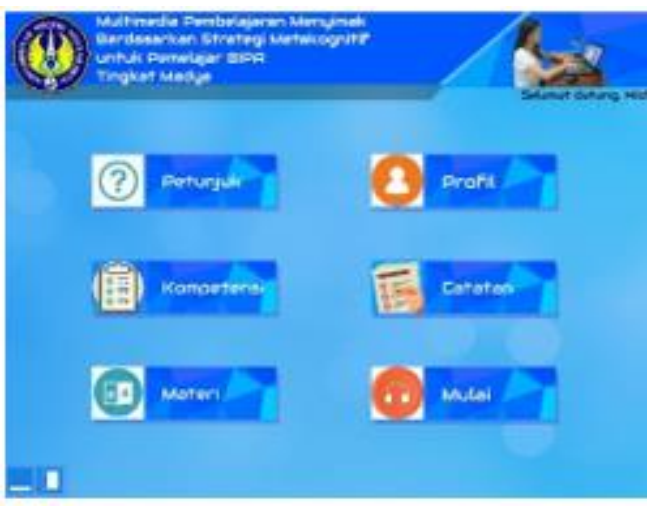

Figure 28: Display of Metacognitive Knowledge Page before Revision

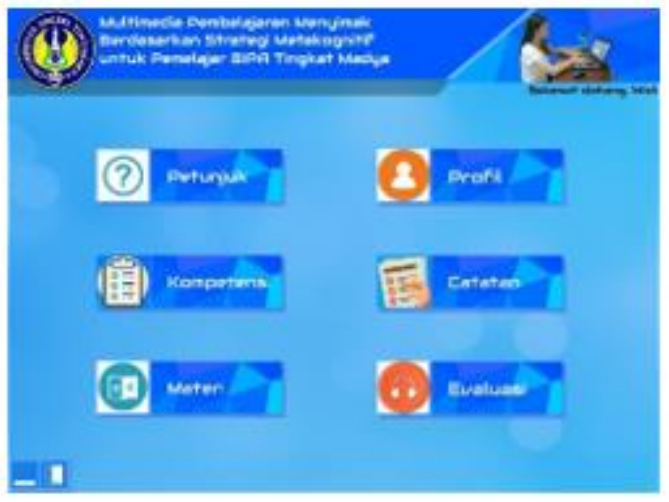

Figure 29: Display of Metacognitive Knowledge Page after Revision 


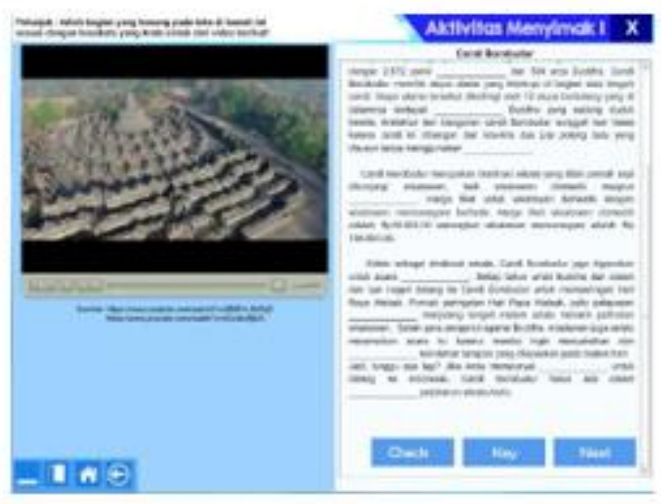

Figure 30: Page Display before Revision

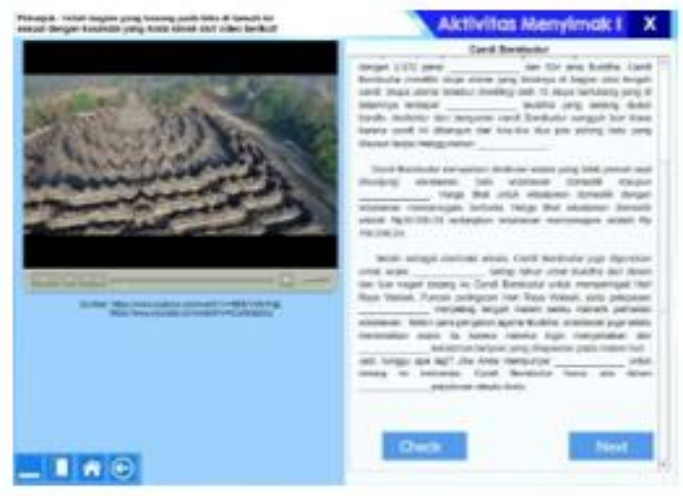

Figure 31: Page Display after Revision

Sixth, the answer key does not need to be displayed on the "Mulai" menu because it is used as an evaluation so that the answer key is only displayed in exercises on the "Materi" menu. The following is the display of key button before and after revision.

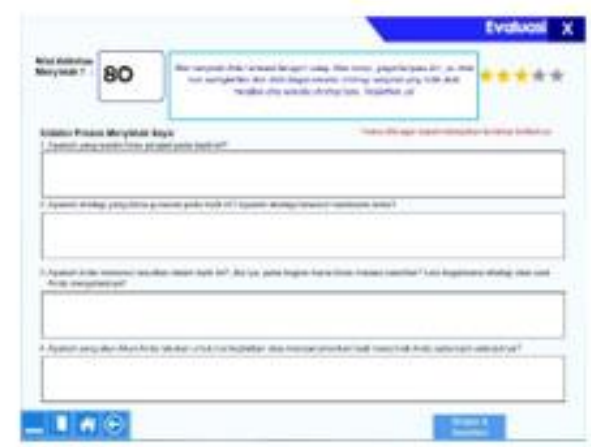

Figure 32: Reflection Page before Revision 


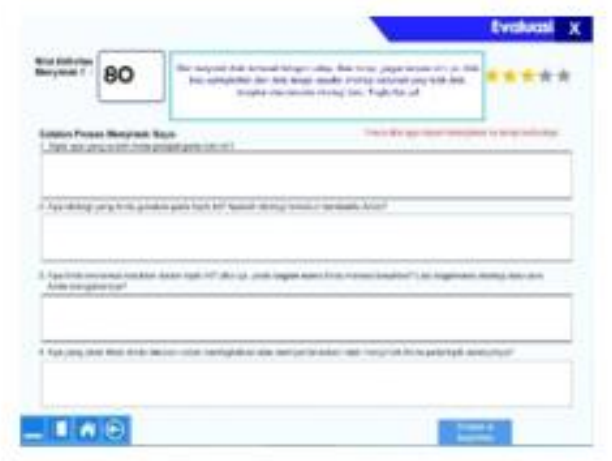

Figure 33: Reflection Page after Revision

After revising the learning multimedia based on the advice of a media expert, the researchers re-validated the learning multimedia to the media expert. At this stage, there was no suggestion for improvement from media expert so that learning multimedia is declared feasible.

Listening learning multimedia based on metacognitive strategies is packaged in a compact disk (CD) and can be operated using a computer or laptop. This learning multimedia can be used classically or independently, both inside and outside the classroom. The form of listening practice in multimedia is in the form of monologues and dialogues, as well as audio and video. The form of practice questions and evaluation in learning multimedia consists of multiple-choice, true-to-false, gaps in a text, and essays or descriptions. There are five themes in this learning multimedia, namely socio-culture, tourism, education, environment, and entertainment. Each theme is divided into three topics so that there are 15 recordings in this learning multimedia. Metacognitive strategies applied in learning multimedia help learners to have self-knowledge, task knowledge, and listening strategy knowledge. In addition, learners can also plan, monitor, and evaluate their listening process and results using this learning multimedia. With these metacognitive strategies, it is hoped that BIPA students can develop their listening skills.

BIPA students or users need to register when first using this learning multimedia. The registration process is done by entering the student's username and password. After that, the user can log in or log in to the learning multimedia by re-entering the name and password used for registration. This is so that the student database (processes and results of listening) can be stored by the system. These registration instructions have been written on the outer cover of learning multimedia to facilitate students when using learning multimedia for the first time. In addition, this learning multimedia is also equipped with a manual so that students can use learning multimedia easily.

This learning multimedia is interactive so that it provides automatic feedback for the learner's answers. There are indicators to assess students' answers so that they know how to listen to them. At the end of the listening activity, students can find out the value obtained along with the value and reinforcement categories based on the value obtained. At the end of the listening activity, students also answer reflective questions related to the listening process as part of a metacognitive strategies. The self-evaluation activity of the listening process will make learners aware of what are still the difficulties so that in future listening 
activities, the students will be able to correct these deficiencies. The scores obtained, answers to listening activities, and answers to self-evaluation questions are stored automatically in the learning multimedia so that learners can open the notes at any time.

One of the characteristics of language learning media compared to other learning media is the presence of cultural elements. Learning media serves as not only a conveyor of language material but also a conveyor of cultural understanding (Kusmiatun, 2015). Based on this, the materials developed in this learning multimedia are also full of Indonesian cultures, such as watching the discussion on the anniversary of the Republic of Indonesia independence contest, listening to the Ande-Ande Lumut fairy tale, and news of angklung celebrations. This integration was done so that students can understand the language and culture in Indonesia through this learning multimedia.

Integrating cultural elements in language learning is a vital aspect that must be done. Language learning, especially foreign language learning, cannot be separated from cultural teaching. Foreign language teachers should provide cultural materials to their learners. Material about culture is not seen as something that stands alone or is separate from language learning but must have a specific context (Kramsch, 2001). This is done so that learners can use their language skills according to the context of the target language. Therefore, in this learning multimedia, elements of Indonesian culture are integrated into listening learning materials.

In addition to the embodiment of Indonesian culture, language teaching should also accommodate the source culture or learners' culture. The target and source cultural content should be equally represented in the teaching of foreign languages so that learners can identify differences in indigenous cultures and target cultures so that they are able to have good intercultural communication skills (McKay, 2003). The embodiment of Chinese culture as a source culture or learner culture in this learning multimedia is contained in discussion questions that are at the planning stage and are included in the self-knowledge section. In general, the discussion questions will lead to the situation and condition of a topic in China. In other words, the discussion questions were directed at the comparison of the topic in Indonesia with China. In addition, some examples of sentences in vocabulary explanations also use Chinese culture so that their source culture can be written in learning.

Some of the advantages of this learning multimedia, namely: (1) there are various elements of learning multimedia, such as text, audio, video, animation, and graphics to help students in listening as well as increase student motivation in practicing listening, (2) learning multimedia is packaged in compact form disks (CDs) and students or instructors do not need to install applications on their computers or laptops so that they can be used directly, (3) learning multimedia is equipped with various buttons to adjust the listening, such as play listening, pause, adjust volume voice, and mute so that students can adjust their listening so that the listening process is comfortable, and (4) students can control the learning process because each student can have a different learning style or practice listening. Thus, after going through a series of product development processes, it can be concluded that listening multimedia based on these metacognitive strategies deserves to be used as an alternative listening media for intermediate level BIPA students. 


\section{Conclusion}

Learning multimedia can be a tool to accommodate the needs of students and teachers in listening learning in the BIPA program. Listening learning multimedia developed has been validated by material experts and media experts who have competence in the field of BIPA and learning media evaluation. Based on the evaluation of material experts and media expert, this learning multimedia gets the "very good" category so that it is considered feasible. Thus, this learning multimedia can be used as a learning media in listening learning in the BIPA program, both inside and outside the classroom. However, this study also has limitations that this learning multimedia has not been tested for its effectiveness in listening learning. Therefore, for further research, experimental research related to learning multimedia can conducted by further researchers. In addition, other researchers are expected to develop listening learning multimedia with different learner levels and types of BIPA programs.

\section{References}

Arsyad, A. (2014). Media pembelajaran. Jakarta: PT Raja Grafindo Persada.

Astuti, W., \& Nurhadi. (2019). Need assessment of interactive multimedia development for listening based on metacognitive strategies for intermediate learners of Bahasa Indonesia for speakers of other languages. Proceedings of the International Conference on Interdisciplinary Language, Literature and Education. Yogyakarta, Indonesia.

Borg, W. R., Gall, M. D., \& Gall, J. P. (1983). Educational research: An introduction (4 $4^{\text {th }}$ ed.). New York: Longman.

Brett, P. (1997). Comparative study of the effects of the use of multimedia on listening comprehension. System, 25(1), 39-53.

Brown, S. (2017). L2 listening. In Eli Hinkel (Ed.), The handbook of research in second language teaching and learning (pp. 201-213). New York: Routledge.

Cairncross, S., \& Mannion, M. (2001). Interactive multimedia and learning: Realizing the benefits. Innovations in Education and Teaching International, 38(2), 156-164.

Chang, A. C., Wu, B. W., \& Pang, J. C. (2013). Second language listening difficulties perceived by lowlevel learners. Perceptual \& Motor Skills, 116, 415-434.

Goh, C. C. M. (2000). A cognitive perspective on language learners' listening comprehension problems. System, 28(1), 55-75.

Goh, C. C. M. (2008). Metacognitive instruction for second language listening development: Theory, practice and research implications. RELC Journal, 39(2), 188-213.

Goh, C. C. M. (2017). Cognition, metacognition, and 12 listening. In Eli Hinkel (Ed.), The Handbook of Research in Second Language Teaching and Learning (pp.214-228). New York: Routledge.

Hulstjin, J. H. (2003). Connectionist models of language processing and the training of listening skills with the aid of multimedia software. Computer Assisted Language Learning, 16(5), 413-425.

Ivers, K. S. \& Barron, A. E. (2002). Multimedia projects in education: Designing, producing, and assessing. New York: John Willey \& Sons.

Kramsch, C. (2001). Context and culture in language teaching. Oxford: Oxford University Press.

Kusmiatun, A. (2015). Mengenal bipa (bahasa Indonesia bagi penutur asing) dan pembelajarannya. Yogyakarta: K-media.

Mayer, R. E. (2007). Learning multimedia. New York: Cambridge University Press.

McKay, S. M. (2003). Toward an appropriate EIL pedagogy: re-examining common ELT assumptions. International Journal of Applied Linguistics, 13(1), 1-22.

Megawati, C. (2014). Pengembangan media pembelajaran bipa tingkat menengah melalui e-book interaktif di program incountry universitas neegeri malang tahun 2014. NOSI, 2(1), 62-70. 
Muliastuti, L. (2017). Bahasa Indonesia bagi penutur asing: Acuan teori dan pendekatan pengajaran. Jakarta: Yayasan Pustaka Obor Indonesia.

Oxford, R. L. (1990). Language learning strategies: What every teacher should know. Boston: Heinle \& Heinle Publishers.

Pun, M. (2013). The use of multimedia technology in English language teaching: A global perspective. Crossing the border: International Journal of Interdisciplinary studies, 1(1), 29-38.

Richards, J. C. (2008). Teaching listening and speaking: From theory to practice. New York: Cambridge University Press

Renukadevi, D. (2014). The role of listening in language acquisition: The challenges \& strategies in teaching listening. International Journal of Education and Information Studies, 4(1), 59-63.

Rost, M. (2011). Teaching and researching listening ( $2^{\text {nd }}$ ed.). United Kingdom: Pearson Education Limited.

Sadiman, A.S., Rahardjo, R., Haryono, A., \& Rahardjito. (2003). Media pendidikan: pengertian, pengembangan, dan pemanfaatannya. Jakarta: PT RajaGrafindo Persada.

Smaldino, S. E., Lowther, D. L., \& Russell, J. D. (2012). Instructional technology and media for learning. Boston: Pearson Education Inc.

Vandergrift, L. (2007). Recent developments in second and foreign language listening comprehension research. Language Teaching, 40(3), 191-210.

Vandergrift, L. \& Goh, C. C. M. (2009). Teaching and testing listening comprehension. In M. H. Long \& C.J. Doughty (Eds.), The Handbook of Language Teaching (pp.395-408). United Kingdom: Wiley Blackwell.

Vandergrift, L. \& Goh, C. C. M. (2012). Teaching and learning: Metacognition in action. London: Routledge.

Vaughan, T. (2001). Multimedia: Making it works. New York: Mc Graw-Hill.

Widoyoko, E.P. (2013). Teknik penyusunan instrumen penelitian. Yogyakarta: Pustaka Pelajar. 